\title{
Celiac Disease, Hepatitis B Vaccine Nonresponse and Endometriosis: What is the Link?
}

\author{
Raffaella Mormile ${ }^{1 *}$ and Giorgio Vittori ${ }^{2}$ \\ ${ }^{1}$ Professor, Division of Pediatrics and Neonatology, Moscati Hospital, Aversa, Italy \\ ${ }^{2}$ Professor, Division of Gynecology, San Carlo di Nancy Hospital, Rome, Italy
}

Celiac disease (CD) is an autoimmune disorder characterized by permanent intolerance to dietary gluten resulting in villous atrophy, inflammation and crypt cell hyperplasia in the proximal small intestine $[1,2]$. Although some CD patients may suffer primarily from gastrointestinal symptoms, CD may be connected with extra intestinal disorders [1,2]. Genetic, environmental and immunological factors have been described as responsible for the disease [1]. With the regard of the participation of the immunological system, CD has been correlated with a Th1-like cytokine production profile with particular involvement of Interferon- $\gamma$ (IFN- $\gamma)$ and interleukin-18 (IL-18) [1-4]. It has been suggested a role of IFN- $\gamma$ gene polymorphisms in CD susceptibility [3]. Moreover, it has been supposed that haplotypes of the promoter region of IL-18 may contribute to CD risk [4]. It has been reported a higher rate of unresponsiveness to Hepatitis $B$ virus (HBV) vaccine series in CD patients than in healthy controls [1]. Interestingly, Th1cytokines gene polymorphisms have also been seen in association with non responders to the HBV vaccine [5-7]. Concordantly, it has been written that genetically determined differences in IFN- $\gamma$ activity could impact on the magnitude of immune response to $\mathrm{HBV}$ vaccination [5]. In addition, it has been shown a link between IFN- $\gamma$ gene polymorphism and susceptibility to development of intrauterine HBV infection $[5,6]$. Furthermore, it has been proved that antibodies to Hepatitis B surface antigen (HBsAb) are related to IL-18 polymorphic variants and that IL18 seems to play an essential role in the regulation of HBV clearance and in the immune response to HBV antigens during spontaneous natural infection or planned vaccination [7]. It has been estimated that more than one third of the world's populations has been infected with HBV with an incidence of 620.000 death per year [1]. Vaccination is an efficacious way to protect the population from common HBV infection [1,5,7]. Non responders may be a significant reservoir of HBV susceptible people that will persist as healthy carriers leading to the spread of the disease $[1,5]$. Thus, the problem of unresponsiveness to HBV represents an important public health matter worldwide [1]. In this respect, new vaccination strategies have been proposed to improve the responsiveness to $\mathrm{HBV}$ vaccine in these subjects at risk [2,5]. In this regard, it has been written that intradermal HBV vaccination may be helpful for the rapid induction of protective level of $\mathrm{HBsAb}$ and may be a safe and effective alternative to intramuscular vaccine administration in celiac patients [8]. CD has also been connected with endometriosis [9]. It is a disorder defined as the presence of endometrial gland and/ or stroma outside the uterus that affects around $10-15 \%$ of women, during menacme [10]. Th1 imbalance has also been described in endometriosis, similarly to $\mathrm{CD}$ and Hepatitis $\mathrm{B}$ vaccine non response [10]. It has been demonstrated that polymorphisms in the IFN- $\gamma$ gene may be linked to the risk of endometriosis [11]. What is more, it has been shown that IL-18 may be a key cytokine in developing the pathogenesis of endometriosis and that polymorphisms in the IL-18 gene have been positively related to the risk of developing endometriosis or the stage of endometriosis [12]. Taken together, we postulate that celiac disease, hepatitis B vaccine non response and endometriosis may share common genetic roots. We hypothesize that these conditions may have similar pathophysiological mechanisms. The commonality among them may be the altered Th1 immune response pattern arisen from the interplay between polymorphic genes of IL 18 and IFN- $\gamma$. For that reason, women suffering from $\mathrm{CD}$ and endometriosis should be tested for anti-HBs response after completion of the vaccine series in order to develop a different immunization schedule to preserve vaccine-induced immunity preventing vertical and horizontal transmission of $\mathrm{HBV}$, mainly in HBV endemic areas. Until today, there are no protocols or guidelines on the management of non responders to hepatitis $B$ vaccine. The intradermally administration of the $\mathrm{HB}$ vaccine could be an alternative strategy in celiac patients with endometriosis unresponders to conventional IM vaccination as already it has been demonstrated in celiac patients [8]. Research studies are needed to define the use of IL18 and IFN $-\gamma$ gene polymorphisms as biomarkers for early diagnosis of unresponsiveness to HBV vaccine evaluating their distribution in populations of various ethnic origin in order to implement personalized vaccine strategies for improving antibody response worldwide.

\section{References}

1. Vitaliti G, Praticò AD, Cimino C, Di Dio G, Lionetti E, et al. (2013) Hepatitis B vaccine in celiac disease: yesterday, today and tomorrow. World J Gastroenterol 19: 838-845.

2. Salvati VM, MacDonald TT, Bajaj-Elliott M, Borrelli M, Staiano A, et al. (2002) Interleukin 18 and associated markers of T helper cell type 1 activity in coeliac disease. Gut 50: 186-190.

3. Rueda B, Martínez A, López-Nevot MA, Mas-Fontao A, Paco L, et al. (2004) A functional variant of IFNgamma gene is associated with coeliac disease. Genes Immun 5: 517-519.

4. Brophy K, Ryan AW, Turner G, Trimble V, Patel KD, et al. (2010) Evaluation of 6 candidate genes on chromosome 11q23 for coeliac disease susceptibility: a case control study. BMC Med Genet 11: 76.

5. Hennig BJ, Fielding K, Broxholme J, Diatta M, Mendy M, et al. (2008) Host genetic factors and vaccine-induced immunity to hepatitis $B$ virus infection. Plos One 3: e1898.

6. Yu H, Zhu QR, Gu SQ, Fei LE, Pu DB (2004) Association of interferon-gamma +874 gene single nucleotide polymorphism with susceptibility to intrauterine HBV infection. Zhonghua Er Ke Za Zhi 42: 421-423.

7. Grzegorzewska AE, Wobszal PM, Mostowska A, Jagodziński PP (2012) Antibodies to hepatitis $B$ virus surface antigen and interleukin 12 and interleukin 18 gene polymorphisms in haemodialysis patients. BMC Nephrology 13: 75.

8. Leonardi S, Miraglia del Giudice M, Spicuzza L, Spina M, La Rosa M (2010) Hepatitis B Vaccine Administered by Intradermal Route in Patients With Celiac

*Corresponding author: Raffaella Mormile, Division of Pediatrics and Neonatology, Moscati Hospital, Via A. Gramsci, 3 -81031, Aversa, Italy, Tel: +390815-001-503, +393-392-045-468; E-mail: raffaellamormile@alice.it

Received May 01, 2013; Accepted May 20, 2013; Published May 24, 2013

Citation: Mormile R, Vittori G (2013) Celiac Disease, Hepatitis B Vaccine Nonresponse and Endometriosis: What is the Link? J Vaccines Vaccin 4: 187 doi:10.4172/2157-7560.1000187

Copyright: (c) 2013 Mormile R, et al. This is an open-access article distributed under the terms of the Creative Commons Attribution License, which permits unrestricted use, distribution, and reproduction in any medium, provided the original author and source are credited. 
Citation: Mormile R, Vittori G (2013) Celiac Disease, Hepatitis B Vaccine Nonresponse and Endometriosis: What is the Link? J Vaccines Vaccin 4: 187. doi:10.4172/2157-7560.1000187

Disease Unresponsive to the Intramuscular Vaccination Schedule: A Pilot Study. AM J Gastroenterol 105: 2117-2119.

9. Stephansson O, Falconer H, Ludvigsson JF (2011) Risk of endometriosis in 11,000 women with celiac disease. Hum Reprod 26: 2896-2901.

10. Huang HY, Yu HT, Chan SH, Lee CL, Wang HS, et al. (2010) Eutopic endometria interleukin-18 system mRNA and protein expression at the level of endometrialmyometrial interface in adenomyosis patients. Fertil Steril 94: 33-39.
11. Kim JJ, Choi YM, Hwang SS, Yoon SH, Lee GH, et al. (2011) Association of the interferon-y gene (CA)n repeat polymorphism with endometriosis. BJOG 118: $1061-1066$

12. Ayaz L, Celik SK, Cayan F, Aras-Ates N, Tamer L (2011) Functional association of interleukin-18 gene -607 C/A promoter polymorphisms with endometriosis. Fertil Steril 95: 298-300. 